\title{
Macrodystrophia lipomatosa of the foot
}

\author{
Sundeep Malla, ${ }^{\oplus}$ Abdul Razik, Chandan J Das
}

Department of Radiodiagnosis, All India Institute of Medical Sciences, New Delhi, Delhi, India

\section{Correspondence to}

Dr Chandan J Das, dascj@yahoo.com

Accepted 16 April 2019

\section{DESCRIPTION}

A 25 -year-old man with no significant family history presented with painless focal enlargement of the first and second digits of the right foot which was first noticed after birth and has progressively increased in size since then. There has been a rapid increase in the size of the digits in the last 5 years with the patient developing difficulty in walking. On examination, the first and second digits showed focal gigantism with upturned great toe due to verrucous soft tissue overgrowth on the plantar aspect (figure 1A,B). The overlying skin showed no ulceration, pigmentation or palpable thrill. Rest of the right foot, vitals and general physical examination were normal.

Radiograph of the right foot showed marked enlargement of the first and second toes with globular lucent areas (consistent with fat proliferation) within. The underlying phalanges showed elongation, broadening as well as proliferative outgrowths (hyperostosis) around the metacarpophalangeal and interphalangeal joints (figure 2A). MRI showed extensive non-encapsulated fibrofatty tissue around the first two toes with no underlying vascular malformation. (figure $2 \mathrm{~B}, \mathrm{C}$ ). Biopsy revealed fragments of adipose tissue without any other spindle cell elements or malignant cells. Correlating the clinicoradiological picture and the biopsy findings, a diagnosis of macrodystrophia lipomatosa (MDL) was made. The patient has now been posted for corrective surgery.
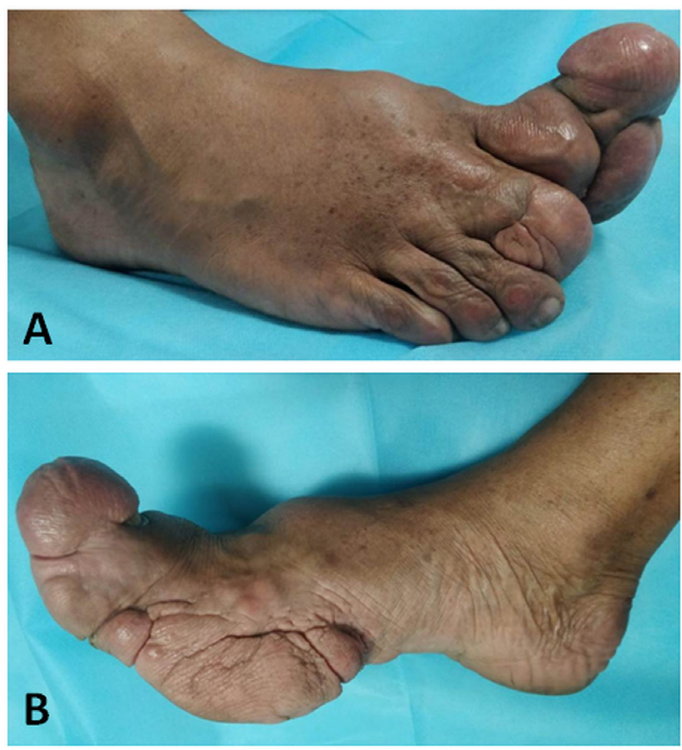

Figure $1 \quad(A, B)$ Clinical photographs of the right foot showing enlargement of the first and second toes with verrucous soft tissue overgrowth on the plantar aspect.
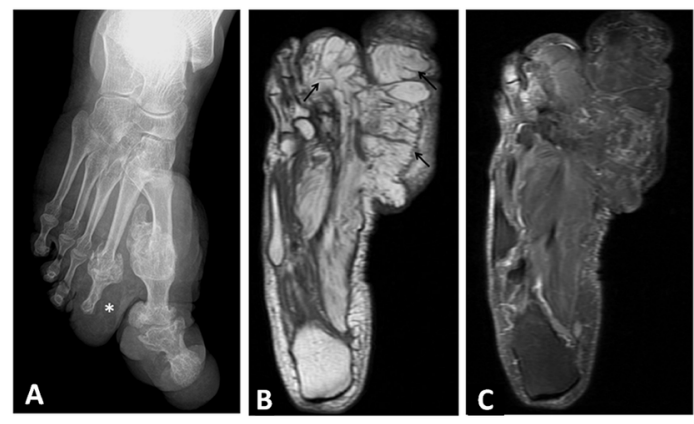

Figure 2 (A) Radiograph (posteroanterior projection) showing elongation and broadening of the phalanges of the first and second toes with proliferative outgrowths (hyperostosis) involving the metacarpophalangeal and interphalangeal joints. Globules of fat lucency (asterisk) are seen within the soft tissue. (B) T1-weighted non-fat saturated and (C) fat saturated MRI, coronal sections, showing non-encapsulated fatty growth (arrows) infiltrating the soft tissue around the first and second toes. The presence of fat is confirmed by the loss of signal in the fat saturated images.

Macrodystrophia lipomatosa is a congenital non-hereditary form of focal gigantism characterised by progressive overgrowth of all the mesenchymal elements (fat, skeletal muscle, nerve sheath and bones) of the digits. ${ }^{1}$ The overgrowth appears to develop along specific sclerotomes and is more common in the lower limbs along the distribution of the plantar nerves. ${ }^{23}$ Volar and distal portion of the digits are more commonly affected. The proliferative fatty growth is unencapsulated can be appreciated as globular lucencies within the soft tissue on radiographs and confirmed on

\section{Patient's perspective}

Since childhood the first two toes of my right foot were enlarged. I used to hide it by wearing socks as I was afraid that my peers would tease me. I had difficulty in wearing shoes and my father used to get a customised shoe made for me. We consulted a doctor who conducted multiple tests and told that I had macrodystrophia lipomatosa. I was told that surgery could reduce the size of the deformity but the chances of recurrence were high. I was apprehensive and hence I refused the surgery. Finally when I was 20 years old, the swelling started to increase in size and it became a more significant cosmetic problem as well as a matter of discomfort while walking. I consulted the surgeon again. A biopsy was taken and I have consented for the surgery. (Translated perspective.) 
MRI. The bones show broadening and elongation along with proliferative (hyperostosis) as well as degenerative changes due to altered biomechanics in the weight-bearing regions. MDL characteristically does not have systemic involvement or family history and occurs sporadically. Treatment is surgical debulking, but it is associated with high recurrence rates. ${ }^{4}$

A close differential on the radiograph is neural fibrolipomatous hamartoma since it also shows localised gigantism with fat lucencies along the distribution of a particular nerve. However, unlike MDL, there is no bony hypertrophy and on MRI, the fat is seen enclosed within the expanded nerve

\section{Learning points}

- Whenever encountered with a case of focal gigantism with no systemic involvement, macrodystrophia lipomatosa should be in the list of differentials.

- On radiographs, the area of gigantism shows globular lucencies of fat as well as proliferative outgrowths and broadening of the underlying bones.

- The presence of bony hypertrophy of the affected digit on the radiograph differentiates it from fibrolipomatous hamartoma which is a close differential. sheath and the nerve fibres are interspersed giving a 'co-axial cable appearance' on the transaxial images. The other differential diagnoses include neurofibromatosis type 1 (plexiform neurofibroma), vascular malformations (sometimes in association with Klippel-Trenaunay-Weber syndrome) and Proteus syndrome. ${ }^{5}$

Contributors SM and AR diagnosed the case and wrote the preliminary draft. Preliminary draft was edited by CJD.

Funding The authors have not declared a specific grant for this research from any funding agency in the public, commercial or not-for-profit sectors.

Competing interests None declared.

Patient consent for publication Obtained.

Provenance and peer review Not commissioned; externally peer reviewed.

\section{REFERENCES}

1 Baruchin AM, Herold ZH, Shmueli G, et al. Macrodystrophia lipomatosa of the foot. I Pediatr Surg 1988;23:192-4.

2 Jain R, Sawhney S, Berry M. CT diagnosis of macrodystrophia lipomatosa. A case report. Acta Radiol 1992;33:554-5.

3 D'Costa H, Hunter JD, O'Sullivan $\mathrm{G}$, et al. Magnetic resonance imaging in macromelia and macrodactyly. Br J Radiol 1996;69:502-7.

4 Boren WL, Henry RE, Wintch K. MR diagnosis of fibrolipomatous hamartoma of nerve: association with nerve territory-oriented macrodactyly (macrodystrophia lipomatosa). Skeletal Radiol 1995;24:296-7.

5 Khan RA, Wahab S, Ahmad I, et al. Macrodystrophia lipomatosa: four case reports. Ital I Pediatr 2010;36:69.

Copyright 2019 BMJ Publishing Group. All rights reserved. For permission to reuse any of this content visit https://www.bmj.com/company/products-services/rights-and-licensing/permissions/

BMJ Case Report Fellows may re-use this article for personal use and teaching without any further permission.

Become a Fellow of BMJ Case Reports today and you can:

- Submit as many cases as you like

- Enjoy fast sympathetic peer review and rapid publication of accepted articles

- Access all the published articles

- Re-use any of the published material for personal use and teaching without further permission

For information on Institutional Fellowships contact consortiasales@bmjgroup.com

Visit casereports.bmj.com for more articles like this and to become a Fellow 